This is an electronic reprint of the original article. This reprint may differ from the original in pagination and typographic detail.

Author(s): Tammelin, Mia; Malinen, Kaisa; Rönkä, Anna; Verhoef, Melissa

Title: Work Schedules and Work-Family Conflict Among Dual Earners in Finland, the Netherlands, and the United Kingdom

Year: $\quad 2017$

Version:

Please cite the original version:

Tammelin, M., Malinen, K., Rönkä, A., \& Verhoef, M. (2017). Work Schedules and Work-Family Conflict Among Dual Earners in Finland, the Netherlands, and the United Kingdom. Journal of Family Issues, 38(1), 3-24.

https://doi.org/10.1177/0192513X15585810

All material supplied via JYX is protected by copyright and other intellectual property rights, and duplication or sale of all or part of any of the repository collections is not permitted, except that material may be duplicated by you for your research use or educational purposes in electronic or print form. You must obtain permission for any other use. Electronic or print copies may not be offered, whether for sale or otherwise to anyone who is not an authorised user. 
Tammelin, M., Malinen, K., Rönkä, A., \& Verhoef, M. (2017). Work Schedules and Work-Family Conflict Among Dual Earners in Finland, the Netherlands, and the United Kingdom. Journal of Family Issues, 38 (1), 3-24. doi:10.1177/0192513X15585810

Work schedules and work-family conflict among dual earners in Finland, the Netherlands, and the United Kingdom

\begin{abstract}
Many European families are affected by the 24/7 economy, but relatively little is known about how working parents experience nonstandard hours. The aim of this study was to analyze the possible associations of dual earners' work schedules and other work related factors' with their experience of time- and strain-based work-family conflict. These phenomena were examined among dual earners living in Finland, the Netherlands, and the United Kingdom, countries which differ in working time practices and policies. Multigroup structural equation modeling was used to analyze cross-cultural data on dual earners with children aged 0 to 12 years $(\mathrm{N}=1000)$. The results showed that working nonstandard schedules was associated with increased time-based work-family conflict, but only among Finnish and British parents. Poorer financial situation, working longer hours, more time spent working at very high speed, and lower work satisfaction were associated with both types of work-family conflict in all countries.
\end{abstract}


Keywords: working time pattern; work-family conflict; dual earners; comparative.

\section{Work Schedules and Work-Family Conflict among Dual Earners in Finland, the Netherlands, and the United Kingdom}

Working mothers and fathers routinely have to cope with the problem of combining work and family responsibilities in their daily life. The growing number of dual earner families and the need to reconcile partners'- often different - work schedules with those of various societal institutions like schools, day-care, shops, transportation and other services, is rendering this task increasingly difficult (e.g., Jacobs \& Gerson, 2001). Work and family researchers have pointed to the importance of taking the experiences of families into account (Jacobs \& Gerson, 2001; Matthews, Priore, Acitell, \& Barnes-Farrell, 2006; Strazdins, Clements, Korda, Broom, \& D’Souza, 2006), as work and family reconciliation cannot simply be explained on the basis of a country's production regime or its welfare institutions alone (Gallie \& Russell, 2009), although these factors play an important role (Pfau-Effinger, 1998; Täht, 2011).

The length of working time and the timing of work are crucial for parents (Adam, 1995), as they influence the amount of time spent away from family commitments and responsibilities. Furthermore, autonomy at work and the predictability of working time define the extent to which individuals can adjust their working time to suit their own or their family's needs (Adam, 1995; Fagan, 2001; Garhammer, 1995). The more working time practices differ from the schedules of society overall, the more difficult it becomes to organize daily life. For example, when families rely on non-familial care of children, they depend on the operating hours of care services, which in many European countries are restricted (Plantenga \& Remery, 2009, p. 32-33).

This study analyzes the experiences of dual earners with young children in three European countries (Finland, the Netherlands, and the United Kingdom), which differ in 
work policies and working time practices. We focus on the associations between nonstandard working time, i.e. work in the evenings, nights, and/or weekends, and experiences of workfamily conflict. The term standard working time means that paid work is carried out between $8 \mathrm{am}$ to $5 \mathrm{pm}$, from Monday to Friday. Working time that departs from this practice is defined as nonstandard working time (Presser, 2003). Despite the significant numbers of dual earners and employees working nonstandard hours in Europe, comparative studies analyzing the linkages between nonstandard work schedules and work-family conflict among dual-earner families are scarce (but see Gallie \& Russell, 2009; Kinnunen \& Mauno, 1998). This study contributes to filling this research gap by adopting a comparative study design to examine in which ways dual earners' work schedules and work-family conflict are related in different cultural contexts.

\section{Working Time Patterns: Extent of Nonstandard Working Time}

Since the establishment of the standardized employment relationship during the 1950s and 1960s, working conditions have changed, and the fundamental temporal institutions of the industrial working time regimes have been eroded. The demand for 'justin-time' production of the service sector challenges the free evenings, nights and weekends that have been core temporal institutions of the traditional industrial working time regime and (male) standard working time (Garhammer, 1995; Negrey 2012; Rubery, Ward, \& Grimshaw, 2006). This is not to say that nonstandard working time is a new phenomenon. For example, there is a long history of shift work in manufacturing. However, recent decades have exposed more sectors of the economy to nonstandard working time (Presser, Gornick, \& Parashar, 2008).

Simultaneously with the changes in the conditions of employment, important changes have occurred in family life. Broadly speaking, across Europe the past thirty years has seen a shift from the male-breadwinner to the dual-earner model, although at a varying 
pace in different countries (Drobnič \& Blossfeld, 2001). It has even been claimed that the rise of dual-earner households is one of the most significant social trends affecting European societies (Smith, 2005, p. 131). Women's employment or working time practices have not followed the ideals of the standard employment relationship, with continuous, full-time work, in most western European countries. There are some exceptions to this, such as Finland, where continuous full-time work has also been the norm among women (Pfau-Effinger, 1998).

Countries and employees are differently affected by the increase in nonstandard working time that characterizes the post-industrial working time regime. Significant differences exist between countries, sectors and workers based on their individual characteristics, such as education, gender and family status (De Beer, 2009; Presser et al., 2008). According to Presser (1995, 2000), Americans are increasingly working during nonstandard times. Despite the lively media debate on the spread of the so-called 24/7 economy in Europe, researchers disagree over whether or not individual European countries can be characterised as 24/7 economies (e.g., De Beer, 2009; Mustosmäki, Anttila, Oinas, \& Nätti, 2011). Yet it is undisputable that a considerable proportion of employees work outside traditional office hours (e.g., Parent-Thirion, Fernández, Hurley, \& Vermeylen, 2007). EU averages range from $17.6 \%$ for shift work, to $27.2 \%$ for evening and night work, and $39.7 \%$ for weekend work (EU Labour Force Survey, 2012a). Together with the increasing proportion of dual-earner families (Margherita, O'Dorchai \& Bosch, 2009), this means that significant numbers of European families are affected by work that is performed outside standard office hours.

According to earlier research, conducted in both the US and Europe, nonstandard work is more common in the service sector, among those with lower education, and among men and younger workers (Presser et al, 2008; Wight, Raley, \& Bianchi, 2008). Richbell, 
Brookes, Brewster, and Woods (2011) note that shift work is most common in the manufacturing and health services sectors, whereas weekend work is most widespread in the transport, retail, and health, social and personal services sectors. Similarly, research (Negrey, 2012; Presser et al., 2008) has shown that the increase in nonstandard hours is strongly related to the expansion of the service sector. In some sectors, nonstandard hours have even become more the rule than standard day work. For example, in Finland the proportion of health service employees working nonstandard hours has exceeded those working a standard day, with $56 \%$ of the personnel working nonstandard hours (Lehto \& Sutela, 2008, p. 132).

Prior results on the associations between family status and nonstandard hours are conflicting. Presser (2003) showed that nonstandard work in the US was particularly typical in families with children, low income families, and single parent families. However, in a study of seven European countries, Presser and colleagues (2008) found that nonstandard working time did not vary according to family status: it was equally common among families with and without children, although minor differences were observed between countries. Looking specifically at the Netherlands, Täht (2011) found nonstandard working times to be more common among employees with children, while Presser and colleagues (2008, p.87) found that, among women, it was less common for mothers to work non-day schedules in the Netherlands and the United Kingdom. In the United Kingdom, however, employed fathers are more likely to work non-day schedules compared to employed men without children (Presser et al., p. 87). In Finland, nonstandard hours are more linked to sector and profession than to family phase (Lehto \& Sutela, 2008).

\section{Work-Family Conflict}

The increase in female participation in the labour force has been accompanied by increased attention to combining work and personal life (e.g., Gallie \& Russell, 2009, p. 446) and by debates on the causes of low fertility rates in countries where work-family policies are 
not implemented (León, 2009, p. 206). Various approaches to describing and studying how work and family (or more broadly work and "life", see Fagan et al., 2012) are reconciled or balanced have been proposed. Despite the conceptual ambiguity, there is a consensus that the work-family interface is both bi-directional and double-layered: work can interfere with home, but home can also interfere with work, and experiences are both negative and positive (e.g., Greenhaus \& Beutell, 1985; Kinnunen \& Mauno, 1998). A substantial amount of workfamily research relies on a conflict orientation, where the demands of work and family are viewed as incompatible because of conflicts caused by time, behaviour, or strain (e.g., Frone et al., 1997; Ruppanner, 2013). The present study focuses on time- and strain-based workfamily conflict among dual earners.

Greenhaus and Beutell (1985, p. 77) defined work-family conflict as “ $a$ form of interrole conflict in which the role pressures from the work and family domains are mutually incompatible in some respect". They distinguished between three types conflict: time-based conflict, strain-based conflict, and behavior-based conflict. Time-based conflict may occur when the time devoted to one role makes it difficult to participate in another role; strainbased conflict means that strain experienced in one role restricts involvement in another role; and behavior-based conflict occurs when specific behavior required in one role is incompatible with expectations in another role (Greenhaus \& Beutell, 1985). Our study concentrates on the associations between time- and strain-based work and family conflict, which vary according to characteristics of the individual and of the work performed. The evidence on the effect of gender on work-family conflict is conflicting. Some studies have found that women experience more conflict than men (e.g., Hill, 2005; Voydanoff, 2005), while others report no gender differences (Kinnunen \& Mauno, 1998; Shaffer, Joblin, \& Hsu, 2011). 
At the individual level, work-family conflict is associated with both work- and family-related demands and resources (e.g., Frone, Russel, \& Cooper, 1997; Voydanoff, 2005). Work demands are associated with both time- and strain-related demands. Earlier research has shown that time demands at work include long hours, nonstandard work hours, and hurriedness at work (Gallie \& Russel, 2009, Grzywacz \& Marks, 2000; Jacobs \& Gerson, 2001; Kinnunen \& Mauno, 1998). Interestingly, autonomy at work, although perceived as a resource reducing work-family conflict (Moen, Kelly, \& Huang, 2008), can, when it is extremely high, be associated with increased work-family conflict (Drobnic \& Guillén Rodriquez, 2011). Strain-related work demands include, for example, job insecurity and changes in work schedules (Mauno \& Kinnunen, 1998; Voydanoff, 2005, see Fagan et al., 2012, for a review). In addition to lowering work demands, work-family conflict can be decreased through the presence of various work related resources, in particular autonomy over working time (Annink \& den Dulk, 2012), job satisfaction (Bruck, Allen, \& Spector, 2002) and part-time work (Grzywacz \& Marks, 2000).

Family-related demands pertain to the presence of children, partner's working hours and the family's economic situation. First, having children in the family potentially increases time demands and strain, particularly in the case of multiple and/or young children (Hill, Yang, Hawkins, \& Ferris 2004; Kinnunen \& Mauno, 1998). Second, while single parents are often in the most difficult situation in the effort to combine work and family, having a working partner can also be a source of conflict. Gallie and Russell (2009, p. 446) point out that because of the increase in the proportion of dual-earning couples, the focus of the analysis should be on the employment schedules of both household members, rather than on individual work patterns. Research on dual earners, however, remains scarce, probably owing to the lack of statistical data that would allow family level investigation. In one of the very few comparative studies on dual-earning couples in Europe, Gallie and Russell (2009, p. 451- 
459) found that work-related factors explained most of the work-family conflict (29\% of the variation) whereas family-related factors explained only $2 \%$. Other family-related demands, such as other care responsibilities or the specific care needs of children, have typically not been included in quantitative research on this topic.

Work-family conflict has effects on employees, such as increased stress, poorer job performance, higher turnover intentions, increased absenteeism, and various negative health outcomes (Carlson \& Kacmar, 2000; Frone, Russell, \& Cooper, 1992; Greenhaus \& Beutell, 1985).

\section{Nonstandard Working Time as Threat and Opportunity in Family Life}

Evening, night and weekend working is often perceived as a risk for family life in the research literature. Nevertheless, results are mixed. On the one hand, Strazdins and colleagues (2004) found associations between nonstandard working time and weakened functioning of the family, and problems in time use. Presser (2000) and Jekielek (2003) reported associations with partnership problems and even increased risk for divorce. Furthermore, several studies have examined the impact of nonstandard work on employees and their families, and found associations with reduced parental well-being (Liu, Wang, Keesler, \& Schneider, 2011), increased relationship conflict and instability (Maume \& Sebastian, 2012; Presser, 2000), and difficulties in parent-child interaction (Han, Miller, \& Waldfogel, 2010; Mills \& Täht, 2010). On the other hand, nonstandard working time may be a purposeful choice rather than a necessity for families (Liu et al., 2011; Presser, 2003; Täht, 2011). Parents may use their nonstandard schedules as a solution to their childcare needs, by maximizing parental coverage of the child (i.e., split shift parenting; Presser, 2003).

Furthermore, the traditional gendered division of household work is no longer so dominant and many parents nowadays share parenting more equally (Craig, 2011; Täht, 2011). Wight (2008) and colleagues reported that night workers in particular may have routines and time- 
use patterns similar to those of standard day working parents, which challenges the negative view of the effects of nonstandard working times. Owing to the lack of suitable data, up-todate cross-national studies analyzing work-family conflict are scarce (but see Allen et al., 2014, Gallie \& Russell, 2009; Rantanen, Kinnunen, Mauno, \& Tilleman, 2011; Van Der Lippe, Jaeger, \& Kops, 2006). More recently, Allen and colleagues (2014) examined the linkages between national policies and work-family conflict, and found a positive association with the presence of policies reducing experiences of work-family conflict. In contrast, Gallie and Russel (2009) reported that welfare policies did not have the expected influence on workfamily conflict among dual-earner couples in seven European countries. Their study showed that working conditions, particularly long working time played a major role in explaining work-family conflict.

\section{This study: Rationale for the comparisons between the three countries}

This study concentrates on Finland, the Netherlands, and the United Kingdom (UK). These countries differ widely in their working time practices, particularly in relation to the length of working time and the extent of nonstandard hours. The EU Labour Force Survey (2012 a,b; see Table 1) shows that whereas there are no substantial differences in paternal employment rates, the employment rate of British mothers is lower than that of their counterparts in the Netherlands and Finland. Turning to working time patterns, significant differences can be seen in the parental part-time employment rate. Part-time work is not typical in Finland, where only $13.9 \%$ of mothers work part-time, whereas this equals $54.5 \%$ in the UK, and $85 \%$ in the Netherlands. This demonstrates that length of working time is an important factor to consider in any analysis of work-family reconciliation.

[INSERT TABLE 1 AROUND HERE]

Differences in working time characteristics reflect differences between countries in their production systems. The basic difference between coordinated and liberal market 
economies lies in concerns the means adopted to secure economic competitiveness. Roughly speaking, in liberal market economies, such as the UK, this has been attempted by weakening workers' rights and working conditions, whereas in coordinated economies, such as the Nordic countries and the Netherlands, efforts have been made to uphold good working conditions through regulation and coordination. (Gallie \& Russell, 2009).

Finland, the Netherlands and the UK also differ in their welfare regimes: Finland represents the social democratic/Scandinavian regime, the Netherlands the corporatist and the UK the liberal (Esping-Andersen, 1990). This in part explains the differences in working time patterns between these countries. Also there are cultural differences and differences in the care policies (Kröger, 2010; Pfau-Effinger, 1998), and renders them interesting targets for a comparative study.

\section{Aims of the Study}

The aim of this study was to find out whether work schedules and other work-related factors are associated with the experience of work-family conflict, operationalized as time and strain-based conflict, among dual earners living in three European countries with different production and welfare systems. We first examined whether respondent's own work schedules are related to work-family conflict by contrasting parents in regular day work with those working nonstandard schedules. Second, we examined whether other work related factors - that is, working hours, changes in working schedules, hurriedness at work and work satisfaction - are associated with dual earners' experiences of work-family conflict. Third, we analyzed whether partner's work schedules and working hours are connected to respondent's experiences of work-family conflict. Finally, we examined whether these associations vary between Finland, the Netherlands and the UK.

\section{Respondents and Procedure}

\section{Methods}


This paper analysed data from a cross-national study titled 'Families 24/7'. The data were drawn from a survey targeted to Finnish, Dutch and British parents with children aged between 0-12 years. Respondents were recruited via childcare organizations, unions and employers, which were invited by letter or email to promote the study. As in Finland dayand-night childcare centres - which are rare in the other two countries - were invited to participate, Finnish parents working nonstandard work schedules are overrepresented in the data. Moreover, due to the procedures used in the recruitment of the respondents, we were not able to evaluate the response rate. The data collection took place between November 2012 and January 2013. Because the same survey was used in all three countries, the survey questionnaire was first prepared in English, and later translated into Finnish and Dutch. After this, back-translation by official translators was used for questions for which no official translation was available.

Our total sample consists of 1,000 dual earning parents (318 from Finland, 334 from the Netherlands and 348 from the UK), who were either married or co-habiting (Table 2). Respondents' age ranged between 21 and 58 years. The respondents from Finland were somewhat younger than those in the Netherlands or UK. The differences were statistically significant. The majority of the sample was female. There were significantly more female respondents in the Dutch and the UK samples than in the Finnish sample. The majority of the respondents had completed tertiary education. There were statistically significant differences in educational level between the countries: in Finland, $42 \%$ of the respondents had completed tertiary education, whereas this was the case for $74 \%$ of the Dutch and $80 \%$ of the British respondents.

The great majority of the respondents were married, and there were no differences between countries in this respect. By default, all the respondents had at least one child between 0 and 12 years, and the age of the youngest child varied across the countries. The 
Dutch families had the youngest children. The majority of the respondents had one or two children. There were significant country differences, with the smallest number of children in the UK, and the highest in Finland.

Comparable data suggest that Finnish nonstandard working parents were overrepresented in our sample and Dutch and British nonstandard working parents somewhat underrepresented (Presser, Gornick, \& Parashar, 2008). Concentrating on shift work in particular, comparable data shows that shift workers are overrepresented in the Finnish sample and, to a lesser extent, in the Dutch sample while somewhat underrepresented in the British sample when concentrating on employees aged 25-49 years old (EU Labour Force Survey 2012b; see Tables 1 and 2).

\section{Measures}

Background information. Background information included the variables of gender $(0=$ man, $1=$ woman $)$, marital status $(0=$ cohabiting, $1=$ married $)$, and age of the respondent, highest level of education obtained $(0=$ lower than tertiary education, $1=$ tertiary education), number of children, and age of the youngest child. In addition, a question on the financial situation of the family ('How would you rate your family's financial situation these days?') was included in the questionnaire $(0=$ the worst possible financial situation, 10 $=$ the best possible financial situation).

Work characteristics. Work schedule was measured with the question 'What is your working time pattern?' There were seven response options $(1=$ day work, $2=$ shift work, $3=$ regular evening work, 4= night work, 5= morning work, 6= irregular working hours, 7= other), which for our analyses were dichotomized as either regular day work schedule $(=0)$ or nonstandard schedule $(=1$; including shift work, regular evening/night/morning work, irregular work and other work schedules). In addition, the respondents were asked whether changes to their work schedule occurred regularly $(0=$ no, $1=y e s)$ and to state their actual 
working hours per week. Hurriedness at work was measured with the following question:

'Does your job involve working at very high speed?' There were seven response categories (7 $=$ all of the time, 1 = never). Work satisfaction in turn was measured with the question 'How satisfied are you with your current job?' (1 = very dissatisfied, $4=$ very satisfied $)$. Identical questions were asked about the partner's work schedule and weekly working hours. The respondent provided the information on his/her partner.

[INSERT TABLE 2 AROUND HERE ]

Work-family conflict. Work-family time conflict was measured using three items (taken from Carlson et al., 2000): 'My work keeps me from my family activities more than I would like', 'The time I must devote to my job keeps me from participating equally in household responsibilities and activities' and 'I have to miss family activities due to the amount of time I must spend on work responsibilities'. There were five response categories (1 $=$ strongly disagree to $5=$ strongly agree). Cronbach's alphas were $.61(\mathrm{NL}), .79(\mathrm{UK})$, and .84 (FIN). Strain-based conflict was also measured with three statements: 'When I get home from work I am often too frazzled to participate in family activities responsibilities', 'I am often so emotionally drained when I get home from work that it prevents me from contributing to my family' and 'Due to all the pressures at work, sometimes when I come home I am too stressed to do the things I enjoy'. There were five response categories $(1=$ strongly disagree to 5 = strongly agree). Cronbach's alphas were $.81(\mathrm{NL}), .86(\mathrm{UK})$, and .87 (FIN).

\section{Statistical Analyses}

The data from the three countries were analyzed using multigroup structural equation modeling (SEM). The analyses were performed using Mplus (version 7; Muthén \& Muthén, 1998 - 2004). The estimation method used was MLR, which produces maximum likelihood parameter estimates with standard errors and a chi-square test statistic that are 
robust to nonnormality and nonindependence of observations (Muthén \& Muthén, 1998 2004). Model fit was assessed using chi-square, Tucker-Lewis index (TLI), root mean square error of approximation (RMSEA), and standardized root mean square residual (SRMR). Good model fit is indicated by a nonsignificant chi-square $p$-value, RMSEA with values of $\leq .06$, SRMR with values of $\leq .08$ and TLI with values of $\geq .95$ (Hu \& Bentler, 1999). The significance of the differences in chi-square values between the nested models was evaluated using a scaled chi-square difference test (Satorra \& Bentler, 1994).

The analysis was started by testing for factorial invariance. Similarity in the measurement level of each latent construct in each group is required in order to test for differences and similarities between different sociocultural groups (e.g., countries, genders) in a meaningful way (Little, 1997). As the focus of the analyses was on comparing predictive paths across the countries (and not on, for example, comparing latent means), this analysis focused on metric invariance (that is, invariance of factor loadings; Milfont \& Fischer, 2010). For this purpose, for both latent factors (time-based conflict and strain-based conflict), the freely estimated measurement models (that is, models with no requirements for invariant loadings) were compared using Satorra-Bentler chi-square difference tests with the models in which the loadings were constrained to be equal between the three countries. When needed, the information given by modification indices was taken into account.

Exogenous variables were included in the models with a stepwise procedure. In step 1, background variables, in step 2, the respondent's work schedule and other work-related variables, and in step 3, work schedule and working hours of the respondent's partner were included in the models. In each step, all the exogenous variables with that had nonsignificant (using $p=.10$ as a limit) path coefficients in each of the three countries were omitted from the analysis before proceeding to the next step. After this, the equality of the path coefficients between the countries was tested for all the exogenous variables with Satorra-Bentler 
difference tests and, where possible, coefficients were constrained to be equal between the countries. Finally, variables with nonsignificant path coefficients (using $p=.05$ as a limit) in all three countries were omitted from the final models.

\section{Results}

\section{Factorial Invariance}

For strain-based conflict (constrained model: $\chi^{2}(4)=6.15, p=.188, \mathrm{TLI}=1.00$, $\mathrm{RMSEA}=.04, \mathrm{SRMR}=.03)$, all loadings, and for time-based conflict (constrained model: $\chi^{2}$ $(3)=1.661, p=.646, \mathrm{TLI}=1.00, \mathrm{RMSEA}=.06, \mathrm{SRMR}=.07)$, all loadings but one could be set equal between the countries on the basis of the fit indices and Satorra-Bentler significance tests. For time-based conflict, the factor loading for the item 'My work keeps me from my family activities more than I would like' was set equal only between Finland and the UK. Thus, these analyses revealed that the requirement of similarity in the structures of the measures used to enable comparisons of paths between countries were sufficiently fulfilled.

\section{Time-Based Conflict}

For time-based conflict, four background variables (financial situation, marital status, education, and gender) had at least nearly significant $(p<.10)$ associations with the latent variable in step 1 . The other three background variables (age of the participant, age of the youngest child and number of children) showed no significant associations with the latent variable and were thus excluded from the following analyses. In step 2, all the work-related variables (nonstandard working time pattern, working hours, working at high speed, work satisfaction, and changes to work schedules) were associated with time-based conflict in at least one of the countries. In step 3, both partner's work schedule and working hours were associated with the latent variable. The Satorra-Bentler difference tests showed that for all the variables, except for participant's work schedule and gender, paths could be set equal between the countries. For gender, paths could be constrained to be equal only between the 
Netherlands and the UK, and for participant's work schedule only between Finland and the UK. On the basis of the final model $\left(\chi^{2}(70)=154.35, p<.001\right.$, TLI $=.87$, RMSEA $=.07$, $\mathrm{SRMR}=.05$ ) experiencing higher time-based work-family conflict was associated with lower financial situation, having more working hours, more time spent working at high speed, feeling less satisfied with one's work, experiencing more changes in work schedules, and having a partner with fewer working hours (see Figure 1). In addition, among the Dutch and British respondents, being female was related to higher work-family conflict, whereas having a nonstandard work schedule was significantly related to higher work-family conflict in Finland and the UK. Marital status, education and partner's work schedule did not show significant associations with time-based conflict after the constraints on the equality of the paths between the countries were removed from the model.

\section{[INSERT FIGURE 1 ABOUT HERE]}

\section{Strain-based Conflict}

In the model for strain-based work-family conflict, predictors of at least marginal significance in step 1 were age of the youngest child, financial situation, education and gender, and in step 2 working hours, working at high speed and work satisfaction. Neither of the partner's work-related variables were connected with strain-based conflict. All the path coefficients, except for the coefficient of working at high speed in the Dutch sample, could be constrained to be equal between the countries. Thereafter, the variables of age of the youngest child and education no longer had statistically significant associations with the latent variable and were thus excluded from the final model. Experiencing higher strain-based work-family conflict was associated with poorer self-reported financial situation, being female, working longer more hours, more time spent working at very high speed and being less satisfied with one's work (for final model: $\chi^{2}(43)=87.93, p<.001, \mathrm{TLI}=.96, \mathrm{RMSEA}=.06, \mathrm{SRMR}=$ $.04)$, as shown in Figure 2. The association between working at high speed and strain-based 
conflict was stronger among the Finnish and the British respondents, compared to their Dutch counterparts.

[INSERT FIGURE 2 ABOUT HERE]

\section{Discussion}

Dual-earner families have become the standard family pattern in Europe, and many parents work outside the 'standard' hours of schools and day-care. These, along with variations in working conditions, are changing the linkages between work and family, bringing both new risks and new opportunities. Our study analysed the associations between working time schedules and experiences of work-family conflict among dual earners. The main contribution of the present study is the use of data from three European countries, Finland, the Netherlands and the UK differing in working time practices, production systems and welfare regimes. Via cross-national comparisons, which remain scarce in this line of research, the role of the macro-context on families becomes more visible. Such a comparative setting can be particularly revealing on how families live their daily lives when the countries concerned have different societal policies on family and work.

We found that whether one works during so called office hours or during nonstandard times was connected with experiences of time-based work-family conflict in two of the countries - Finland and the UK - but not in the Netherlands. In addition, in the UK and Finland, experiencing changes in working schedules and, interestingly, having a partner with short weekly working hours, were related to higher time-based conflict. A nonstandard work pattern can theoretically have both a positive and negative impact on the family. It seems that in Finland and the UK, in particular, nonstandard working times are experienced as particularly difficult for the family and thus associated with time-based work-family conflict. Finnish and British families working standard hours showed a better fit with prevailing conditions, cultural expectations and services. In the Netherlands, work-family conflict was 
not associated with nonstandard working time. It may be that services and policies that have a better fit nonstandard working time are available to dual earner families in the Netherlands, compared to the situation in the other two countries. Cultural norms concerning childcare and working times may also have an impact. The better fit between nonstandard working time and family in the Netherlands may also be due to employment regulations, protection of workers, higher wages, strict opening hours and work schedule regulations (Mills \& Täht, 2010).

Strain-related work-family conflict, in turn, was not associated with working time schedules, but rather with other conditions of work such as hurriedness, long hours and work satisfaction. These conditions were similarly related to time-based conflict across all the samples. Furthermore, individual and family characteristics, such as a poor family economic situation and being female, were associated with strain-based conflict. In previous research, nonstandard working time, particularly shift work, has been found to act as a stressor, resulting in adverse health outcomes (Costa, 2003). Our study did not find an association between nonstandard work schedule and increased strain-based conflict. This might be due to the mixed characteristics of nonstandard working time in our sample, which included not only on shift work but also on other types of nonstandard hours, such as regular evening or early morning work.

The gender of the parent matters. We found that compared to men, women experienced more strain-based conflict in all three countries and more time-based conflict in the Netherlands and the UK.

Our study also investigated how the work situation of one's partner was related to the experience of work-family conflict. We found only partial support for an association between these phenomena. Experiencing higher time-based conflict was found to be connected with having a partner with fewer weekly working hours. Partner's working time 
pattern, on the other hand, was not associated with either types of work-family conflict. This is somewhat surprising, as we expected to find an effect of partner's work schedule when controlling for the characteristics of the respondent's working time. The absence of an association might be due to the restricted information gathered on the partner in our data. This finding challenges the notion that household characteristics have a significant role in experiences of work and family conflict, and is in line with previous research (Gallie \& Russell, 2009). However, the experiences of one member of the family may, and often do, spill over to other members of the family, such as children and partner (see Kinnunen, Feldt, Mauno \& Rantanen, 2010; Matthews et al., 2006). Especially with the increase in dualearning couples across countries, experiences of work spillover from one partner to another will be of increasing importance in the future.

Employed parents in families with a poor economic situation reported higher timeand strain-related conflict. Given the importance of family income to the employed population, it is surprising how little attention has been paid to the role of economic situation and work-family balance (see Fagan et al., 2012, p. 39). To cite an exception, Schieman and Young (2011) found associations between economic hardship and family-to-work conflict in the US. As our results suggest that individuals' perceptions on their family's economic situation is relevant when considering work-family conflict, more research needs to be done on this issue.

This study also has its limitations. The first one concerns the representativeness of the data. The samples were not randomly selected; instead a lot of effort was put into targeting families that worked nonstandard hours. The data were collected via a web survey, and there was no possibility to evaluate the response rate. It is difficult, therefore, to know whether the results are biased in some way. Although similar recruitment strategies were used in the three countries to render the samples as comparable as possible, the country-specific 
samples differed from each other in certain key characteristics, such as demographics and the prevalence of nonstandard work. Although these factors were controlled for in the SEM models used, it is possible that this did not account for all the differences between the samples'. Comparable data suggest that Finnish nonstandard working parents were overrepresented in our sample and Dutch and British nonstandard working parents somewhat underrepresented (Presser, Gornick, \& Parashar, 2008). In addition, the data were crosssectional. Consequently, no causal interpretations can be made on the basis of this study. Moreover, it should be noted that the data were based on self-reports and thus the results of the study are dependent on the respondents' ability and willingness to report on the phenomena of interest. Last, owing to our limited number of respondents, we were not able to differentiate between spouses with respect to nonstandard work schedules. This could have prevented us from finding significant results regarding strain-based conflict, because effects of the different types of work schedules were lumped together.

This study shows that work schedules are an important factor when analyzing timebased work-family conflict, particularly among dual-earner couples with young children. It seems that research should not concentrate solely on the length of working hours. Employment not only means a period of time away from the family, but its timing and requirements (e.g., rush or not) vary. Each of these means different demands and resources in combining work and family. Among dual-earner couples, the location of household work during a day or a week has a considerable effect on the daily life of the families that is not wholly negative. Whether schedules are self-selected (a choice) or a not is an important issue meriting further study. There is clear need for more comparative research on the 24/7 economy, societal and workplace practices, and family life.

\section{References}


Adam, B. (1995). Time watch. The Social analysis of time. Cambridge: Polity Press.

Allen, T. D., Herst, D. E. L., Bruck, C. S., \& Sutton, M. (2000). Consequences associated with work to-family conflict: A review and agenda for future research. Journal of Occupational Health Psychology, 5, 279-308.

Annink, A. \& den Dulk, L. (2012). Autonomy: The panacea for self-employed women's work-life balance? Community, Work \& Family, 15, 383-402.

Bruck, C.S, Allen, T. D. \& Spector, P. E. (2002). The relation between work-family conflict and job satisfaction: A finer-grained analysis. Journal of Vocational Behavior, 60, 336353.

Carlson, D., Kacmar, M. K., \& Williams, L. J. (2000). Construction and initial validation of a multidimensional measure of work-family conflict. Journal of Vocational Behaviour, $56,249-276$.

Costa, G. (2003). Shift work and occupational medicine: An overview. Occupational Medicine 52, 83-88.

Craig, L. (2011). Non-standard work schedules, work-family balance and the gendered division of childcare. Work Employment \& Society, 25 (2), 274-291.

De Beer, P. (2009). De hardnekkigheid van de negen-tot-vijfeconomie. [The persistency of the nine-to-five economy]. In: H. Van den Hurk \& C. Van Limborg (Eds.), Or en arbeidstijden (pp. 37-47). Alphen aan den Rijn: Kluwer.

Drobnič, S. \& Guillén Rodríguez, A. (2011). Tensions Between Work and Home: Job Quality and Working Conditions in the Institutional Contexts of Germany and Spain. Social Politics, 18 (2), 232-268.

Drobnič, S. \& Blossfeld H.-P. (2001). 'Careers of Couples and Trends in Inequality'. In Blossfeld H.-P. \& Drobnič S. (ed.) Careers of Couples in Contemporary Societies. A 
Cross-National Comparison of the transition from Male Breadwinner to Dual Earner Families. Oxford: Oxford University Press, UK, 371-386.

Esping-Andersen, G., 1990. The Three Worlds of Welfare Capitalism. Cambridge: Polity Press.

EU Labour Force Survey. (2012a). Population in employment working during unsocial hours. Retrieved from: http://epp.eurostat.ec.europa.eu/portal/page/portal/statistics/search_database

EU Labour Force Survey. (2012b). Working time. Retrieved from: http://epp.eurostat.ec.europa.eu/portal/page/portal/statistics/search_database

Fagan, J. (2001). The temporal reorganization of employment and the household rhythm of work schedules. The implications for gender and class relations. American Behavioral Scientist, 44, 1199-1212.

Fagan, C., Lyonette, C., Smith, M., \& Saldaña-Tejeda, A. (2012). The influence of working time arrangements on work-life integration or 'balance': A review of the international evidence. Geneva: International Labour Office.

Frone, M., \& Russel, M., \& Cooper, L. M. (1997). Relation of work-family conflict to health outcomes: A four-year longitudinal study of employed parents. Journal of Occupational \& Organizational Psychology, 70, 325-336.

Gallie D., \& Russell, H. (2009). Work-family conflict and working conditions in Western Europe. Social Indicators Research, 93, 445-467.

Garhammer, M. (1995). Changes in working hours in Germany. The resulting impact on everyday life. Time \& Society, 4, 167-203.

Greenhaus, J.H., \& Beutell, N.J. (1985). Sources of conflict between work and family roles. Academy of Management Review, 10, 76-88. 
Grzywacz, J. G., \& Marks, N., F. (2000). Reconceptualizing the work-family interface: An ecological perspective on the correlates of positive and negative spillover between work and family. Journal of Occupational Health Psychology, 5, 111-126.

Han, W-J., Miller, D. P., \& Waldfogel, J. (2010). Parental work schedules and adolescents' risky behaviors. Developmental Psychology, 46(5), 1245-1267.

Hill, J. E. (2005). Work-family facilitation and conflict, working fathers and mothers, workfamily stressors and support. Journal of Family Issues, 26, 793-819.

Hill, J. E., Yang C., Hawkins A. J. \&Ferris M. (2004). A Cross-Cultural Test of the WorkFamily Interface in 48 Countries. Journal of Marriage and Family, 66, 1300 - 1316

Hu, L., \& Bentler, P. (1999). Cutoff criteria for fit indexes in covariance structure analysis: Coventional criteria versus new alternatives, Structural Equation Modeling, 6(1), 1-55. Jacobs J., \& Gerson K. (2001). Overworked individuals or overworked families? Explaining trends in work, leisure, and family time. Work and Occupations, 28, 40-63.

Jekielek, S. (2003). Non-standard work hours and the relationship quality of dual-earner parents (Doctoral dissertation). Retrieved from https://etd.ohiolink.edu

Kinnunen, U., \& Mauno, S. (1998). Antecedents and outcomes of work family conflict among employed women and men in Finland. Human Relations, 51, 157-177.

Kinnunen U, Feldt T, Mauno S, Rantanen J. (2010). Interface between work and family: A longitudinal individual and crossover perspective. Journal of Occupational and Organizational Psychology 83 (1), 119-137.

Kröger, T. (2010). Lone mothers and the puzzles of daily life: Do care regimes really matter? International Journal of Social Welfare, 19, 390-401.

Lehto, A. M., \& Sutela H. (2008). Työolojen kolme vuosikymmentä. Työolotutkimusten tuloksia 1977-2008 (Three decades of working conditions. Results from quality of work life surveys 1977-2008). Tilastokeskus, Helsinki. 
León, M. (2009). Gender equality and the European employment strategy: The work/family balance debate. Social Policy and Society, 8, 197-209

Lippe, T. van der, Jager, A. \& Kops, Y. (2006). Work-family balance in European countries. Acta Sociologica, 49(3), 303-319.

Little, T. D. (1997). Mean and covariance structures (MACS) analyses of cross-cultural data: Practical and theoretical issues. Multivariate Behavioral Research, 32, 53-76.

Liu, H., Wang, Q., Keesler, V., \& Schneider, B. (2011). Non-standard work schedules, workfamily conflict and parental well-being: A comparison of married and cohabiting unions. Social Science Research, 40, 473-484.

Margherita, A., O’Dorchai, S., \& Bosch, J. (2009). Reconciliation between work, private and family life in the European Union. Luxembourg: Office for Official Publications of the European Communities.

Matthews, R. A., Priore, R. E., Acitell, L. K., \& Barnes-Farrell, J. L. (2006). Work-torelationship conflict: Crossover effects in dual-earner couples. Journal of Occupational Health Psychology, 11, 228-240.

Maume, D., \& Sebastian, R. (2012). Gender, Nonstandard Work Schedules, and Marital Quality. Journal of Family and Economic Issues 33 (4), 477-490.

Milfont, R. \& Fischer, R. (2010). Testing measurement invariance across groups: Applications in cross-cultural research. International Journal of Psychological Research, 111-121.

Mills, M., \& Täht, K. (2010). Nonstandard work schedules and partnership quality: Quantitative and qualitative findings. Journal of Marriage and Family, 72, 860-875.

Moen, P., Kelly, E., \& Huang, Q. (2008) Work, family and life-course fit: Does control over work time matter? Journal of Vocational Behaviour, 73, 414-425. 
Mustosmäki, A., Anttila, T., Oinas, T., \& Nätti, J. (2011). Job quality trends in Europe. Implications for work-life balance. In S. Drobnic, \& A. Guillén (Eds.), Work-life balance in Europe. The role of job quality (pp. 17-41). Basingstoke, UK: Palgrave Macmillan.

Muthén, L.K., \& Muthén, B.O. (1998 - 2004). Mplus User's Guide ( $7^{\text {th }}$ ed.). Los Angeles, CA: Muthén \& Muthén.

Negrey, C.(2012). Work time: conflict, control, and change. Cambridge, UK: Polity Press.

Parent-Thirion, A., Fernández Macías, E., Hurley, J., Vermeylen, G. (2007). Fourth European Working Conditions Survey. European Foundation for the Improvement of Living and Working Conditions.

Pfau-Effinger, B. (1998). Gender cultures and the gender arrangement - a theoretical framework for cross-national comparisons on gender. Innovation: The European Journal of Social Sciences, 11, 147-166.

Plantenga. J., \& Remery, C. (2009). The provision of childcare services: A comparative review of 30 European countries. Brussels: European Commission DG for Employment, Social Affairs and Equal Opportunities.

Presser, H. B. (1995). Job, family and gender: Determinant of nonstandard work schedules among employed Americans in 1991. Demography, 32, 577-598.

Presser, H. B. (2000). Nonstandard work schedules and marital instability. Journal of Marriage and Family, 62, 93-110.

Presser, H. B. (2003). Working in a 24/7 economy: Challenges for American families. New York, NY: Russell Sage Foundation.

Presser, H. B., Gornick J.C., \& Parashar, S. (2008). Nonstandard work schedules in twelve European countries: A gender perspective. Monthly Labor Review, 131, 83-103. 
Rantanen, J., Kinnunen, U., Mauno, S., \& Tilleman, K. (2011). Introducing theoretical approaches to work-life balance and testing a new typology among professionals. In S. Kaiser, M. J. Ringlstetter, D. R. Eikhof \& M. P. E. Cunha (Eds), Creating balance?! International perspectives on the work-life integration of professionals (pp. 27-47). Heidelberg, Germany: Springer.

Richbell, S., Brookes, M., Brewster, C., \& Wood, G. (2011). Non-standard working time: An international and comparative analysis. International Journal of Human Resource Management, 22, 945-962.

Rubery, J.,Ward, K., \& Grimshaw, D. (2006). Time, work and pay: Understanding the new relationships. In J.Y. Boulin, M. Lallement, J. C. Messenger, \& F. Michon (Eds.), Decent working time. New trends, new issues (pp. 123-151). International Labour Office, Geneva.

Ruppanner, L. (2013). Conflict between work and family: An investigation of four policy measures. Social Indicators Research,110, 327-347.

Satorra, A., \& Bentler, P. M. (1994). Corrections to test statistics and standard errors in covariance structure analysis. In A. von Eye \& C. C. Clogg (Eds.), Latent variables analysis: Applications for developmental research (pp. 399-419).Thousand Oaks, CA: Sage.

Shaffer, M., Joblin, J., \& Hsu, H. (2011). Expanding the boundaries of work-family research: A review and agenda for future research International Journal of Cross Cultural Management, 11, 221-268.

Schieman, S., \& Young, M. (2011). Economic hardship and family-to-work conflict: The importance of gender and work conditions. Journal of Family and Economic Issues, 32, 46-61. 
Smith, M. (2005). Dual earning in Europe: Time and occupational equity. Work, Employment \& Society, 29, 131-138.

Strazdins, L., Korda, R. J., Lim, L., Broom, D. H., \& D’Souza, R. M. (2004). Around-theclock: Parent work schedules and children's well-being in a 24-h economy. Social Science \& Medicine, 59, 1517-1527.

Strazdins, L., Clements, M. S., Korda, R. J., Broom, D. H. \& D’Souza, R. M. (2006). Unsociable work? Nonstandard work schedules, family relationships, and children's well-being. Journal of Marriage and Family, 68, 394-410.

Täht, K. (2011). Out of sync? The determinants and consequences of nonstandard schedules for family cohesion: The Netherlands within a comparative perspective (Doctoral dissertation). Faculty of Social Sciences. Amsterdam, The Netherlands: Free University Amsterdam.

Wight, V., Raley S., \& Bianchi, S. (2008). Time for children, one's spouse and oneself among parents who work nonstandard hours. Social Forces, 87, 243 -272.

Voydanoff, P. (2005). Work demands and work-to-family and family-to-work conflict: Direct and indirect relationships. Journal of Family Issues, 26, 707-726.

Table 1 Employment patterns in Finland, the Netherlands and the UK

\begin{tabular}{lcccccc}
\hline & \multicolumn{2}{c}{ Finland } & \multicolumn{2}{c}{ Netherlands } & \multicolumn{2}{c}{ UK } \\
\cline { 2 - 7 } & Women & Men & Women & Men & Women & Men \\
\hline Parental employment rate (per cent) $^{\mathrm{a}}$ & 77.2 & 88.8 & 77.9 & 92.3 & 67.4 & 86.9 \\
Parental part-time employment (per cent) $^{\mathrm{a}}$ & 13.9 & 3.3 & 85.0 & 14.9 & 54.5 & 9.0 \\
Shift work (per cent) $^{\mathrm{b}}$ & 25.5 & 20.5 & 7.1 & 10.0 & 16.3 & 21.0 \\
Evening work (per cent of total employees) $^{\mathrm{b}}$ & 20.1 & 20.0 & 25.4 & 27.3 & 8.5 & 11.5 \\
Night work (per cent of total employees) $^{\mathrm{b}}$ & 7.4 & 10.8 & 6.8 & 11.3 & 4.6 & 8.0 \\
Work on Saturdays (per cent of total $_{\text {employees) }}^{\mathrm{b}}$ & 19.7 & 17.1 & 23.3 & 20.8 & 21.3 & 29.3 \\
Work on Sundays (per cent of total $_{\text {employees) }}^{\mathrm{b}}$ & 14.4 & 13.6 & 18.0 & 14.1 & 14.5 & 19.1 \\
\hline
\end{tabular}


Source: EU Labour Force Survey 2012a and 2012b.

${ }^{a}$ Parental status: at least one child under age 15 living at home, or a dependent child aged 15-24. ${ }^{b}$ Only for employees aged 25-49, the age range within which it is most likely to have children living at home. 
Table 2. Dependent and Independent Variables $(\mathrm{N}=1,000)$

\begin{tabular}{|c|c|c|c|c|}
\hline & $\begin{array}{l}\text { Finnish sub-sample } \\
(n=318)\end{array}$ & $\begin{array}{l}\text { Dutch sub-sample } \\
(n=334)\end{array}$ & $\begin{array}{l}\text { British sub-sample } \\
(n=348)\end{array}$ & Difference test \\
\hline & $\mathrm{M}$ or $\%$ & $\mathrm{M}$ or $\%$ & $\mathrm{M}$ or $\%$ & \\
\hline \multicolumn{5}{|l|}{ Background variables } \\
\hline Gender: proportion of women & 78 & 85 & 83 & $\mathrm{x}^{2}(2)=6.99, \mathrm{p}=.030$ \\
\hline Marital status: proportion of marrieds & 73 & 73 & 80 & $n s$ \\
\hline Education: proportion of tertiary education & 42 & 74 & 80 & $x^{2}(8)=349.52, p=.001$ \\
\hline Financial situation $(0=$ worst $; 10=$ best $)(S D)$ & $5.71(2.13)$ & $6.43(1.85)$ & $5.44(2.15)$ & $\mathrm{F}(2)=21.19 \mathrm{p}=.000$ \\
\hline Age in years (SD) & $35.04(5.67)$ & $35.77(5.46)$ & $38.12(5.67)$ & $F(2)=17.65, p=.000$ \\
\hline Age of youngest child (SD) & $4.16(2.48)$ & $2.51(2.54)$ & $4.06(2.96)$ & $\mathrm{F}(2)=39.30, \mathrm{p}=.000$ \\
\hline Number of children (SD) & $1.91(0.81)$ & $1.87(0.84)$ & $1.74(0.68)$ & $\mathrm{F}(2)=3.93, \mathrm{p}=.020$ \\
\hline \multicolumn{5}{|l|}{ Respondent: } \\
\hline \multicolumn{5}{|l|}{ Work -related information } \\
\hline Work schedule: regular day-work & 29 & 70 & 76 & $x^{2}(4)=174.89, p=.001$ \\
\hline shift work & 44 & 14 & 13 & \\
\hline other & 28 & 16 & 12 & \\
\hline Weekly working hours (SD) & $37.12(8.89)$ & $30.96(9.13)$ & $36.04(11.15)$ & $\mathrm{F}(2)=36.18, \mathrm{p}=.000$ \\
\hline $\begin{array}{r}\text { Hurriedness at work: } \% \text { working at high } \\
\text { speed all the time }\end{array}$ & 12 & 6 & 10 & $\mathrm{x}^{2}(12)=51.58, \mathrm{p}=.000$ \\
\hline Work satisfaction: & & & & $x^{2}(8)=32.99, p=.000$ \\
\hline$\%$ very satisfied & 18 & 29 & 27 & \\
\hline$\%$ quite satisfied & 63 & 64 & 55 & \\
\hline \multicolumn{5}{|l|}{ Partner: } \\
\hline \multicolumn{5}{|l|}{ Work -related information } \\
\hline Work schedule: \% of regular day-work & 47 & 78 & 73 & $\mathrm{x}^{2}=100.94, \mathrm{p}=.000$ \\
\hline Weekly work hours (SD) & $41.04(8.03)$ & $39.58(10.57)$ & $40.54(10.96)$ & $\mathrm{F}(2)=2.31, \mathrm{p}=.099$ \\
\hline \multicolumn{5}{|l|}{ Independent variables } \\
\hline Work-family time conflict (SD) & $2.68(1.07)$ & $2.14(.71)$ & $2.65(.99)$ & $\mathrm{F}(2)=34.43, \mathrm{p}=.000$ \\
\hline Work-family strain conflict (SD) & $2.60(1.10)$ & $2.13(.82)$ & $2.90(1.06)$ & $\mathrm{F}(2)=50.67, \mathrm{p}=.000$ \\
\hline
\end{tabular}


Figure 1. Final SEM model for time-based work-family conflict.Estimates with significance asterisks are unstandardized path coefficients. Estimates between square brackets refer to standardized path coefficients for the Finnish, Dutch and British sample, respectively. ${ }^{*}=p<.05 ;{ }^{* *}=p<.01 ;{ }^{* * *}=p<.001$

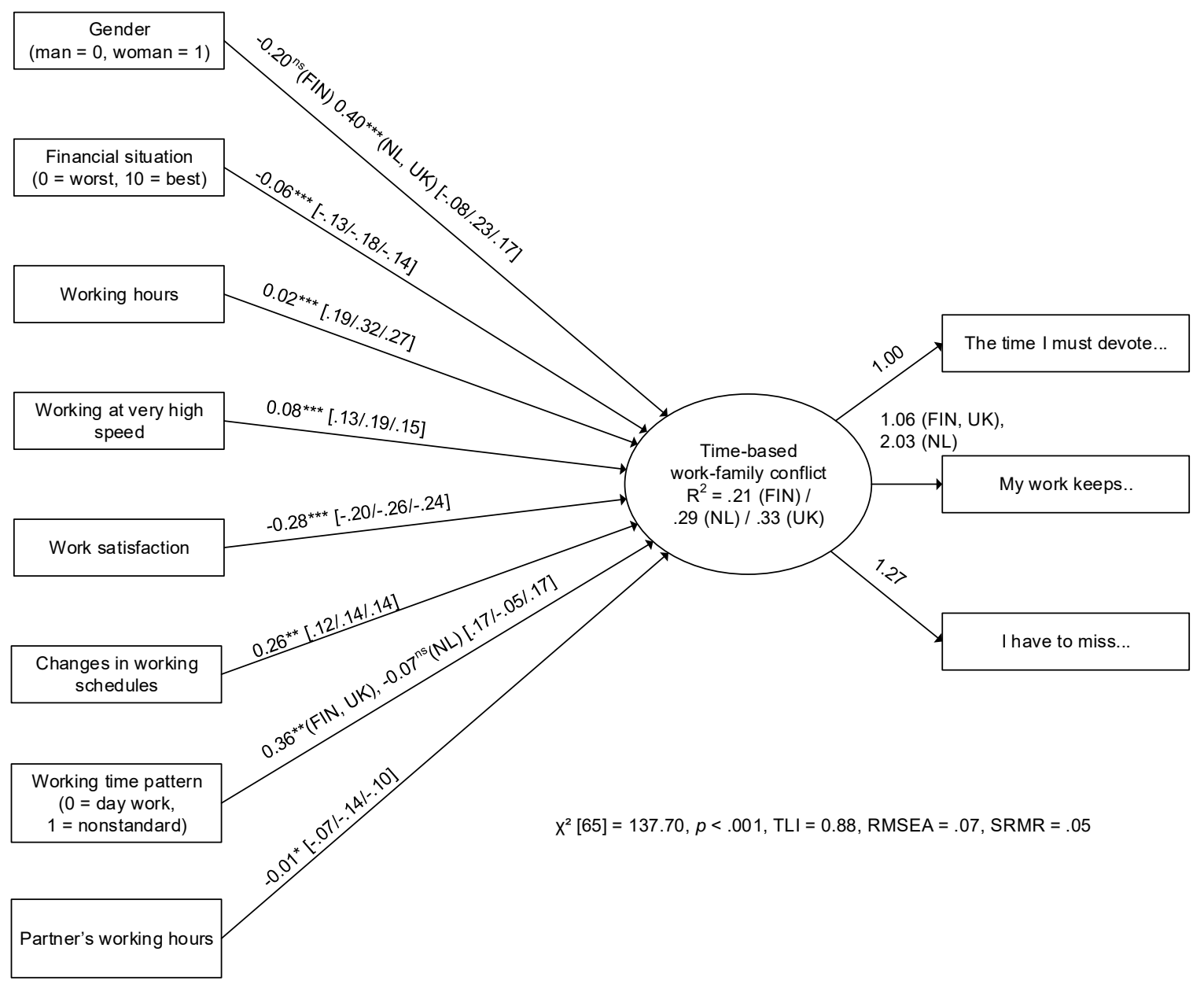


Figure 2.Final SEM model for strain-based work-family conflict. Estimates with significance asterisks are unstandardized path coefficients. Estimates in between square brackets refer to standardized path coefficients for the Finnish, Dutch and British sample, respectively. ${ }^{*}=p<.05 ;{ }^{* *}=p<.01 ;{ }^{* * *}=p<.001$

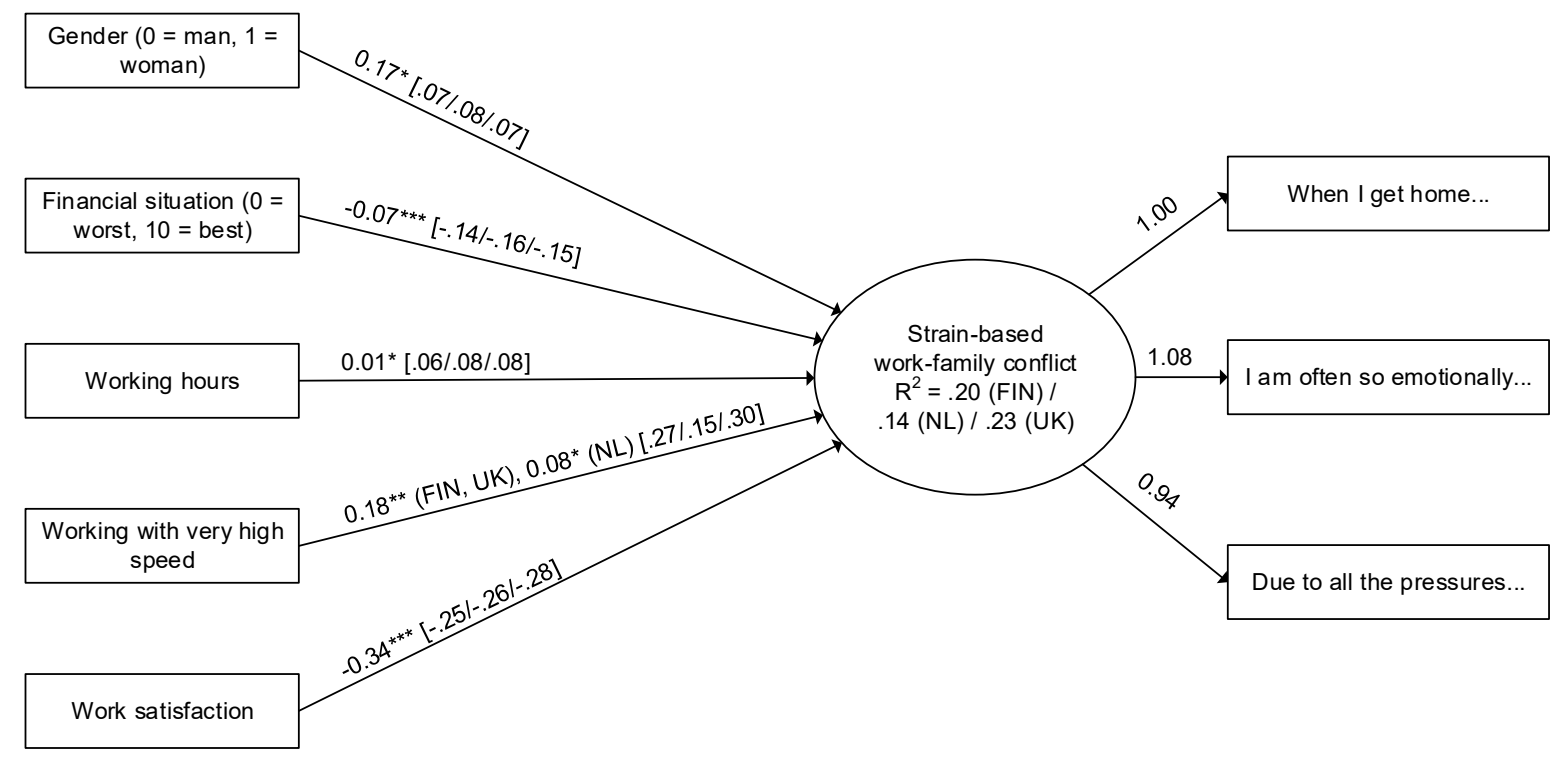

$\mathrm{X}^{2}[43]=87.93, p<.001, \mathrm{TLI}=0.96, \mathrm{RMSEA}=.06, \mathrm{SRMR}=.04$ 